\title{
MODEL PEMBELAJARAN CONNECTING, ORGANIZING, REFLECTING, DAN EXTENDING (CORE) UNTUK MENINGKATKAN KREATIVITAS SISWA DI SMK MUHAMMADIYAH 13 SIBOLGA
}

\author{
Iwan Setiawan Nasution, Benny Sofyan Samosir \\ Pendidikan Matematika, FKIP Universitas Muhammadiyah Tapanui Selatan \\ bennysofyansamosir@um-tapsel.ac.id
}

DOI : 10.31604/ptk.v1i3.213-221

\begin{abstract}
The problem in this research is the lack of ability of creativity in students. To fix the issue, on the research learning model applied to Connecting, Organizing, Reflecting, and Extending (CORE). Research objectives for the enhancement of creativity and learning activities of students in learning mathematics through the application of the model of learning a CORE class XI Accounting SMK Muhammadiyah 13 Sibolga. This type of research is a research action class. Where the subject of this research is the grade XI Accounting SMK Muhammadiyah 13 Siboga consisting of 36 students. While the techniques and data-collecting instruments namely observation and tests. Research results can be seen from the students ' creativity ability test on cycle I with a percentage of $53 \%$ in cycle II an increase in the percentage of $82 \%$ with an increase of $29 \%$. Activity levels of students against mathematics increases, it is retrieved from $63 \%$ percentage of the cycle I, and $82 \%$ in cycle II increased by $18 \%$. The ability of the teacher to manage learning percentage of $72 \%$ in cycle I and $94 \%$ in cycle II, with an increase of $23 \%$. Based on the results of this study, it can be concluded that the model Connecting, Organizing and Extending (CORE) can increase creativity in learning mathematics processed XI accounting SMK Muhammadiyah 13 Sibolga.
\end{abstract}

Keywords: Creativity, activity, Connecting Learning Model, Organizing and Extending (CORE).

\begin{abstract}
Abstrak
Masalah dalam penelitian ini adalah rendahnya kemampuan kreativitas siswa. Untuk mengatasi masalah tersebut, pada penelitian ini diterapkan model pembelajaran Connecting, Organizing, Reflecting, dan Extending (CORE). Tujuan penelitian untuk meningkatan kreativitas dan aktivitas belajar siswa dalam pembelajaran matematika melalui penerapan model pembelajaran CORE kelas XI Akuntansi SMK Muhammadiyah 13 Sibolga. Jenis penelitian ini adalah penelitian tindakan kelas. Dimana subjek penelitian ini adalah siswa kelas XI Akuntansi SMK Muhammadiyah 13 Siboga yang terdiri dari 36 orang siswa. Sedangkan teknik dan alat pengumpul data yaitu tes dan observasi. Hasil penelitian dapat dilihat dari tes kemampuan kreativitas siswa pada siklus I dengan persentase $53 \%$ pada siklus II terjadi peningkatan yaitu dengan persentase $82 \%$ dengan peningkatan sebesar 29\%. Kadar aktivitas siswa terhadap pelajaran matematika meningkat, hal ini diperoleh dari persentase $63 \%$ siklus I, dan $82 \%$ pada siklus II meningkat sebesar $18 \%$. Kemampuan guru mengelola


PeTeKa (Jurnal Penelitian Tindakan Kelas dan Pengembangan Pembelajaran)

Vol 1 No 3 Tahun 2018 Hal 213-221

pembelajaran persentase sebesar $72 \%$ pada siklus I dan $94 \%$ pada siklus II, dengan peningkatan sebesar $23 \%$. Berdasarkan hasil penelitian ini, dapat disimpulkan bahwa model Connecting, Organizing dan Extending (CORE) dapat meningkatkan kreativitas dalam pembelajaran matematika dikelas XI akuntansi SMK Muhammadiyah 13 Sibolga.

Kata Kunci:Kreativitas, Aktivitas, Model Pembelajaran Connecting, Organizing dan Extending (CORE).

\section{PENDAHULUAN}

Belajar adalah suatu aktivitas
mental yang berlangsung dalam
interaksi aktif antara seseorang dalam
lingkungan, dan menghasilkan
perubahan-perubahan
pengetahuan, keterampilan, dan nilai sikap yang bersifat relative konstan dan berbekas.

Matematika merupakan salah satu bidang studi yang ada pada semua jenjang pendidikan, mulai dari tingkat sekolah dasar hingga perguruan tinggi. Bahkan matematika diajarkan di taman kanak-kanak secara Informal. Belajar matematika merupakan suatu syarat cukup untuk melanjutkan pendidikan ke jenjang berikutnya. Karena dengan belajar matematika, kita akan belajar bernalar secara kritis, kreatif, dan aktif. Matematika merupakan ide-ide abstrak yang berisi simbol-simbol, maka konsep-konsep matematika harus dipahami terlebih dahulu sebelum memanipulasi simbol-simbol itu (Susanto, 2012).

Kemampuan pemahaman siswa disekolah terhadap materi yang diajarkan belum sepenuhnya tergali dengan baik dikarenakan banyak faktor yang membuat kemampuan siswa tidak berkembang secara baik. Oleh karena itu kemampuan pemahaman siswa disekolah harus ditingkatkan. Pemahaman merupakan aspek kemampuan siswa yang termasuk ke dalam ranah kognitif (Samosir dkk, 2018).

Kreativitas melibatkan karakteristik yang berhubungan dengan kemampuan untuk menemukan atau melakukan sesuatu yang baru Karkockiene (2005). Kreativitas dalam matematika didefinisikan sebagai kemampuan untuk melihat dan memilih penyelesaian dalam matematika (Sriraman, 2011). Kreativitas merupakan kemampuan seseorang untuk menciptakan sesuatu yang sama sekali baru atau kombinasi dari karyakarya yang telah ada sebelumnya menjadi suatu karya baru yang dilakukan melalui interaksi dengan lingkungannya untuk menghadapi permasalahan dan mencari alternatif pemecahannya melalui cara-cara berpikir divergen (Richardo dkk, 2014).

Model pembelajaran CORE merupakan model pembelajaran altrenatif yang dapat digunakan untuk mengaktifkan siswa dalam membangun pengetahuannya sendiri. Dengan diterapkannya pembelajaran model CORE, siswa dapat terbantu dalam melatih komunikasi matematik siswa (Hariyanto, 2016). Model pembelajaran CORE kurang efektif digunakan kepada siswa yang memiliki KAM rendah. Hal ini didasarkan pada hasil temuan penelitian yaitu tidak terdapat perbedaan yang signifikan pada kemampuan berpikir kritis dan disposisi matematis kelompok siswa yang 
memiliki kemampuan awal matematika rendah (Siregar dkk, 2018).

\section{METODE}

Penelitian ini direncanakan di SMK Muhammadiyah 13 Sibolga. Yang beralamat jalan DE. Sutan Bungaran PGB NO. 20 A Sibolga tahun Pelajaran 2017/2018. Subjek dalam penelitian adalah kelas XI Akuntansi SMK Muhammadiyah 13 Sibolga tahun pelajaran 2017/2018 yang berjumlah 36 orang siswa yang terdiri dari 6 orang siswa laki - laki, dan 30 orang siswa perempuan. Jenis penelitian adalah penelitian tindakan kelas (Classroom Action Research) yang menggunakan data pengamatan terhadap jalannya proses pembelajaran di kelas, data tersebut kemudian dianalisis melalui tahapan dalam siklus. Menurut Sanjaya (2010) penelitian tindakan kelas adalah penelitian tindakan yang dilakukan di kelas dengan tujuan memperbaiki/meningkatkan mutu praktik pembelajaran. Jadi, PTK merupakan kegiatan yang dilakukan oleh guru atau peneliti untuk memperbaiki atau meningkatkan kualitas pembelajaran matematika terkait dengan meningkatkan kemampuan kreativitas siswa melalui model pembelajaran Connecting, Organizing, Reacting, dan Extending (CORE).

\section{Siklus I}

\section{Perencanaan}

a) Menganalisis kurikulum untuk mengetahui kompetensi dasar dan indikator yang akan disampaikan pada siswa dengan mennggunakan model Connecting, Organizing, Reacting, dan Extending (CORE).

b) Mempersiapkan bahan pelajaran yang sesuai dengan skenario pembelajaran Connecting,
Organizing, Reacting, dan Extending (CORE).

c) Mempersiapkan sumber, bahan, dan alat bantu yang dibutuhkan.

d) Menyusun lembar kerja siswa (LKS).

\section{Perlakuan}

a) Siswa membaca dan memahami materi yang terdapat pada sumber belajar.

b) Guru terlebih dahulu menjelaskan tentang materi yang akan dipelajari yang terdapat pada buku sumber.

c) Guru mengajak dan melatih siswa terlebih dahulu untuk memecahkan masalah dengan cara berpendapat tentang pertanyaan yang dilontarkan guru kepada siswa.

d) Guru membentuk kelompok peserta didik dan masing - masing siswa berdiskusi membahas masalah (kasus) yang sudah dipersiapkan oleh guru.

e) Masing masing kelompok menetapkan jawaban sementara dari masalah tersebut, siswa harus berusaha memecahkan masalah sehingga betul-betul yakin bahwa jawaban tersebut benar-benar sesuai.

f) Siswa menarik kesimpulan dan mengerjakan lembar kerja siswa (LKS).

\section{Pengamatan}

a) Melihat dari keaktifan dalam memberikan tanggapan, masukan dan pertanyaan.

b) Mengamati siswa dengan cara memakai format observasi yang sudah disiapkan berupa catatan anekdot untuk mengumpulkan data.

c) Menilai hasil tindakan dengan menggunakan lembar kerja siswa (LKS).

\section{Refleksi Sesuai Dengan Evaluasi}

a) Menganalisis data yang diperoleh dari pelaksanaan pembelajaran. 
PeTeKa (Jurnal Penelitian Tindakan Kelas dan Pengembangan Pembelajaran)

Vol 1 No 3 Tahun 2018 Hal 213-221

b) Melakukan evaluasi tindakan yang telah dilakukan meliputi evaluasi mutu, jumlah dan waktu dari setiap macam tindakan.

c) Melakukan perbaikan pelaksanaan tindakan sesuai hasil evaluasi untuk digunakan pada siklus berikutnya.

\section{Siklus II}

Setelah siklus I dilaksanakan dan hasil perbaikan yang diharapkan belum tercapai pada tingkat penguasaan yang telah diterapkan, maka tindakan masih perlu dilanjutkan pada siklus II, pada siklus II diadakan perencanaan kembali dengan mengacu pada hasil refleksi I, siklus II ini merupakan kesatuan dari kegiatan perencanaan, pelaksanaan tindakan, observasi, dan refleksi seperti yang dilakukan pada siklus I.

\section{HASIL DAN PEMBAHASAN}

\section{Hasil Tes Kreativitas Siswa Siklus I}

Siklus I merupakan pembelajaran dengan pokok bahasan deret aritmatika. Model pembelajaran Connecting, Organizing, Reflcting and Extending (CORE) diterapkan pada siswa SMK Muhammadiyah 13 Sibolga. Pada siklus I terdiri dari 2 kali pertemuan dilaksanakan tes kreativitas, maka hasil yang didapat dari tes tersebut tes kreativitas siswa pada siklus I siswa yang tuntas hanya 53\% atau 19 orang siswa, dan $47 \%$ yang tidak tuntas atau 17 orang siswa.

Tabel 1: Tes Kreativitas Siswa Siklus I

\begin{tabular}{ccc}
\hline \multicolumn{2}{l}{ Interval Jumlah Siswa } & Persentase \\
\hline $20-33$ & 2 & $3 \%$ \\
$34-45$ & 6 & $17 \%$ \\
$46-57$ & 5 & $14 \%$ \\
$58-69$ & 7 & $19 \%$ \\
$70-81$ & 12 & $34 \%$ \\
$82-93$ & 4 & $13 \%$ \\
Total & $\mathbf{3 6}$ & $\mathbf{1 0 0 \%}$ \\
\hline
\end{tabular}

Penguasaan siswa terhadap materi pembelajaran masih tergolong cukup dan belum memenuhi tingkat keberhasilan, karena jumlah siswa yang memperoleh dan kategori minimal cukup adalah 19 orang siswa atau 53\% dari 36 siswa yang mengikuti tes. Sehingga belum sesuai dengan kriteria yang ditentukan yaitu $80 \%$. Maka perlu dilakukan refleksi untuk perbaikan siklus berikutnya. Untuk lebih jelasnya dapat dilihat pada diagram berikut:

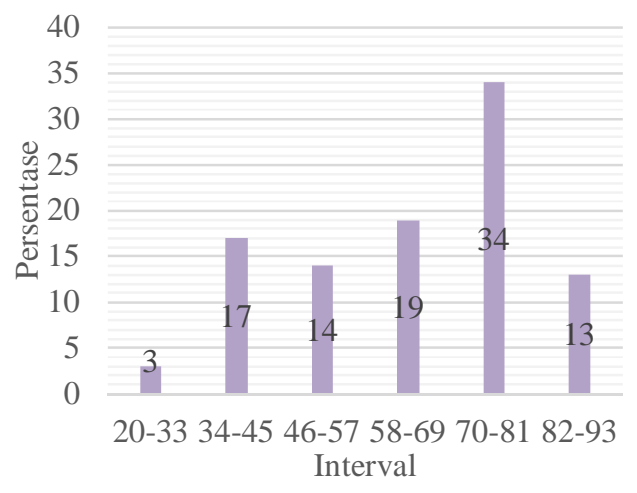

Gambar 1: Tes Kreativitas Siswa Siklus I

Dapat disimpulkan bahwa kriteria penilaian belum mencapai indikator keberhasilan $80 \%$ dari jumlah siswa dengan kriteria "baik". Dari hasil ini maka peneliti akan mengadakan perbaikan pada siklus berikutnya untuk meningkatkan kemampuan kreativitas siswa. Untuk itu guru bersama peneliti merancang kegiatan yang lebih baik atau sesuai dengan kriteria "baik".

\section{Hasil Observasi Aktivitas Siswa Siklus I \\ Hasil observasi aktivitas siswa masih "cukup baik". Untuk itu diharapkan pada siklus selanjutnya aktivitas siswa meningkat dari siklus I. hal ini menunjukkan bahwa siswa belum berantusias terhadap pembelajaran yang diterapkan oleh}


peneliti sehingga kualifikasi nilai yang didapatkan berada pada kategori baik dengan persentase nilai $80 \%$. Dalam kategori tersebut dapat observer ketahui, bahwa siswa masih kurang dalam melakukan diskusi aktif dengan pasangannya, berani dan aktif dalam mengemukakan pendapat, memberikan kesimpulan terhadap materi pembelajaran sehingga nilai yang diperoleh masih kurang. Secara keseluruhan pencapaian aktivitas siswa pada siklus I dapat dilihat pada gambar berikut ini:

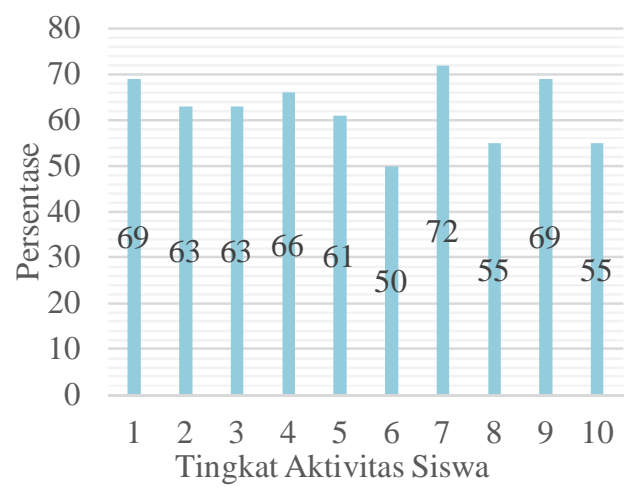

\section{Gambar 2: Observasi Aktivitas} Siswa Siklus I

Keterangan:

a) Mempersiapkan buku catatan dan buku pelajaran.

b) Mengikuti dengan seksama segala sesuatu yang sedang disampaikan guru.

c) Siswa menyimak pertanyaan atau isu yang terkait dengan pelajaran.

d) Siswa berpikir kritis dalam menyimak pertanyaan-pertanyaan atau menjawab pertanyaanpertanyaan yang diajukan guru.

e) Memperhatikan dengan sungguhsungguh, mencatatnya.

f) Melakukan diskusi aktif dengan pasangannya.

g) Siswa menyelesaikan latihan soal yang diberikan guru. h) Siswa berani dan aktif dalam mengemukakan pendapatnya.

i) Siswa bertanya kepada guru dan siswa lainnya untuk memecahkan masalah tentang materi yang belum dimengerti.

j) Siswa memberikan kesimpulan terhadap materi pembelajaran.

Hasil observasi aktivitas siswa dengan model pembelajaran Connecting, Organizing, Reacting, and Extending (CORE) memperoleh 62\% sedangkan aktivitas siswa yang direncanakan dalam penelitian ini adalah $\geq 80 \%$, maka disimpulkan penelitian ini akan dilanjutkan. Jika aktivitas siswa meningkat, maka kemampuan kreativitas siswa juga meningkat. Dari hasil yang di dapat guru PTK, peneliti dan observer berdiskusi untuk mendapatkan solusi agar ativitas siswa ini meningkat. Hasil diskusi akan dijadikan perbaikan pada siklus berikutnya.

\section{Hasil Refleksi Siklus I}

\section{Tes Kemampuan Kreativitas Siswa}

Pada siklus I hasil refleksi yang ditemukan oleh peneliti, siswa masih ada yang ribut dalam kelas dikarenakan masih banyak siswa yang diganggu oleh temannya sendiri yang mengakibatkan siswa tersebut tidak mampu menguasai materi dan pada saat diuji coba dengan soal-soal masih banyak siswa yang belum mampu menjawab sesuai dengan langkah-langkah kemampuan kreativitas siswa. Hal ini dikarenakan siswa tidak mengerti maksud dan bahasa soal yang diujikan sehingga siswa cenderung malas dalam menyelesaikan soal. Berdasarkan hasil tes kemampuan kreativitas siswa, bahwa kriteria penilaian yang telah ditetapkan masih belum terpenuhi $\geq 80 \%$. Dari hasil ini maka peneliti akan melanjutkan ke siklus berikutnnya untuk meningkatkan kemampuan kreativitas siswa. 
PeTeKa (Jurnal Penelitian Tindakan Kelas dan Pengembangan Pembelajaran)

Vol 1 No 3 Tahun 2018 Hal 213-221

\section{Aktivitas Siswa}

Dari hasil observasi aktivitas siswa terlihat belum dapat mencapai tujuan yang diharapkan. Dari kategori aspek yang dinilai kualifikasi nilai masih cukup. Hal ini menunjukkan aktivitas siswa masih pasif dalam pembelajaran. Untuk itu pada siklus selanjutnya akan ditingkatkan.

\section{Hasil Tes Kreativitas Siswa Siklus II}

Melihat hasil analisis dari penelitian tindakan kelas siklus I diperoleh hasil kemampuan kreativitas siswa dan aktivitas siswa masih jauh dari persentase yang diharapkan. Sejalan dengan hal tersebut, pelaksanaan model pembelajaran Connecting, Organizing, Reacting, and Extending (CORE) belum terlaksana dengan baik. Untuk peneliti kembali melanjutkan penelitian pada siklus II dengan melaksanakan tahap yang sama seperti pada siklus I dengan perbaikan yang direncanakan. Tes kemampuan kreativitas siswa pada siklus II siswa yang tuntas $82 \%$ atau 30 orang siswa, dan 3 orang siswa yang tidak tuntas.

Tabel 2: Tes Kreativitas Siswa Siklus II

\begin{tabular}{ccc}
\hline Interval & $\begin{array}{c}\text { Jumlah } \\
\text { Siswa }\end{array}$ & Persentase \\
\hline $20-33$ & 3 & $10 \%$ \\
$34-45$ & 1 & $3 \%$ \\
$46-57$ & 1 & $3 \%$ \\
$58-69$ & 9 & $24 \%$ \\
$70-81$ & 13 & $36 \%$ \\
$82-93$ & 9 & $24 \%$ \\
Total & $\mathbf{3 6}$ & $\mathbf{1 0 0 \%}$ \\
\hline
\end{tabular}

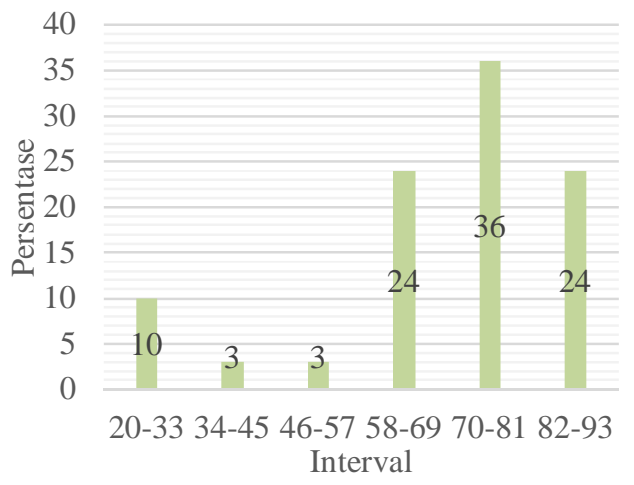

Gambar 3: Tes Kreativitas Siswa Siklus II

Tingkat kemampuan kreativitas siswa telah terpenuhi dengan kriteria penilaian yaitu $82 \% \geq 80 \%$. Dari hasil tersebut maka dapat disimpulkan bahwa kemampuan kreativitas siswa mengalami peningkatan jika dibandingkan dengan siklus I. Dilihat dari persentase hasil tes dari siklus I ke siklus II yaitu 19 orang siswa atau $62 \%$ yang mencapai kriteia minimal "baik" menjadi $82 \%$ atau 30 orang siswa.

\section{Hasil Observasi Aktivitas Siswa Siklus II}

Hasil pengamatan terhadap aktivitas siswa dalam pembelajaran selama 2 kali pertemuan pada siklus II ini dapat dilihat hasil observasi tersebut disajikan dalam diagram berikut:

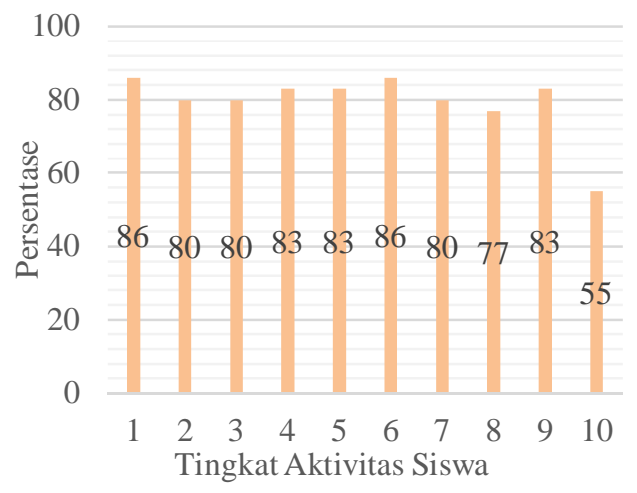

Gambar 4: Observasi Aktivitas Siswa Siklus II 
Keterangan:

a) Mempersiapkan buku catatan dan buku pelajaran.

b) Mengikuti dengan seksama segala sesuatu yang sedang disampaikan guru.

c) Siswa menyimak pertanyaan atau isu yang terkait dengan pelajaran.

d) Siswa berpikir kritis dalam menyimak pertanyaan-pertanyaan atau menjawab pertanyaanpertanyaan yang diajukan guru.

e) Memperhatikan dengan sungguhsungguh, mencatatnya.

f) Melakukan diskusi aktif dengan pasangannya.

g) Siswa menyelesaikan latihan soal yang diberikan guru.

h) Siswa berani dan aktif dalam mengemukakan pendapatnya.

i) Siswa bertanya kepada guru dan siswa lainnya untuk memecahkan masalah tentang materi yang belum dimengerti.

j) Siswa memberikan kesimpulan terhadap materi pembelajaran.

Dari gambar 4.5 hasil observasi aktivitas siswa dengan model pembelajaran Connecting, Organizing, Reacting, and Extending (CORE) dapat dilihat bahwa hasil observasi aktivitas siswa sudah meningkat dengan pembelajaran yang ditetapkan oleh peneliti. Hal ini menunjukkan bahwa siswa berantusias terhadap pembelajaran yang diterapkan oleh peneliti. Sehingga kualifikasi nilai yang didapatkan berada pada kategori "baik" dengan persentase nilai $82 \%$ atau sudah mencapai $80 \%$. Hasil yang didapat sesuai dengan hasil yang diharapkan, maka siklus ini dihentikan.

\section{Hasil Refleksi Siklus II \\ Kemampuan Kreativitas Siswa}

Pada siklus II siswa sudah mampu menguasai materi, sudah terbiasa dengan bahasa soal, maksud soal, sudah mampu memahami soal yang diberikan peneliti dengan benarterkait dengan kemampuan kreativitas siswa, sehingga penelitian ini dihentikan pada siklus II karena tujuan penelitian sudah tercapai yaitu $80 \%$ dengan kategori "Baik".

\section{Aktivitas Siswa}

Jika ditinjau dari segi aktivitas siswa pada siklus II ini, kadar aktivitas siswa lebih baik dari sikulus I. Hal ini terlihat dari hasil observasi aktivitas siswa siklus II, yang memperoleh kategori "Baik". Dilihat dari setiap aspek dalam mengikuti pembelajaran. Dari uraian di atas, penelitian diberhentikan pada siklus ini karena terlihat aktivitas siswa dalam pembelajaran sudah maksimal. Maka penelitian tidak dilanjutkan lagi karena hasil yang didapat sudah terpenuhi.

\section{Pembahasan}

\section{Peningkatan Kemampuan Kreativitas Siswa}

Hasil tes kemampuan kreativitas siswa dari siklus I dan siklus II akan dilihat pada gambar dibawah ini:

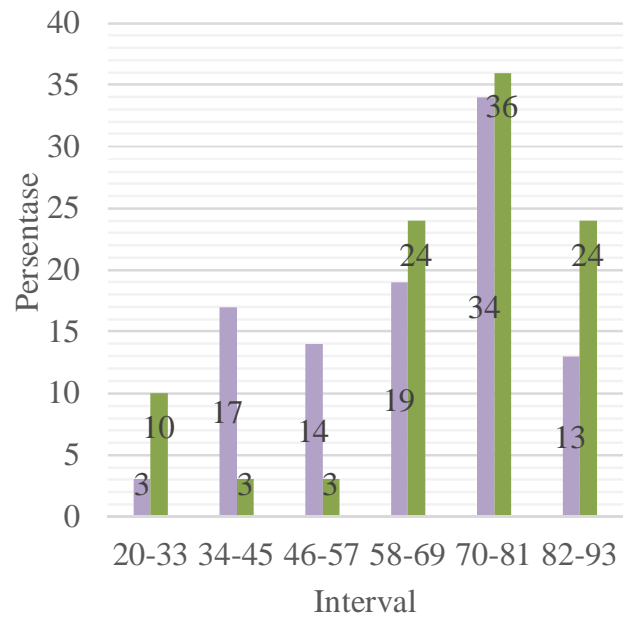

Gambar 5: Tes Kreativitas Siswa Siklus I \& II 
PeTeKa (Jurnal Penelitian Tindakan Kelas dan Pengembangan Pembelajaran)

Vol 1 No 3 Tahun 2018 Hal 213-221

Di tinjau dari tingkat kemampuan kreativitas siswa, setelah pemberian tindakan pada siklus I sebanyak 2 kali pertemuan, siswa diberikan tes dan diperoleh sebanyak 19 orang siswa dengan persentase $53 \%$ dari 36 orang siswa pada kategori "cukup baik". Sedangkan 17 orang siswa belum mencapai tingkat yang diharapkan. Hal ini disebabkan karena: 1) siswa belum melakukan kegiatan pembelajaran dengan baik disebabkan diskusi kelompok yang dilakukan belum berjalan dengan maksimal, 2) siswa belum mampu mampu menerapkan pemahaman yang dimilikinya, 3) siswa masih kurang berani dalam hal mengajukan/menjawab pertanyaan, 4) siswa kurang teliti dalam mengerjakan soal tes yang diberikan. Pada siklus II terdapat 30 orang siswa dengan persentase $82 \%$ dari 36 orang siswa pada kategori "Baik". ini berarti ada peningkatatan dari hasil siklus I sampai siklus II

Peningkatan Aktivitas Belajar Matematika Siswa

Model pembelajaran Conecting, Organizing, Reacting, and Extending (CORE) dapat meningkatkan aktivitas siswa menjadi lebih baik karena dapat meningkatkan aktivitas belajar siswa sesuai pencapaian yang diharapkan.

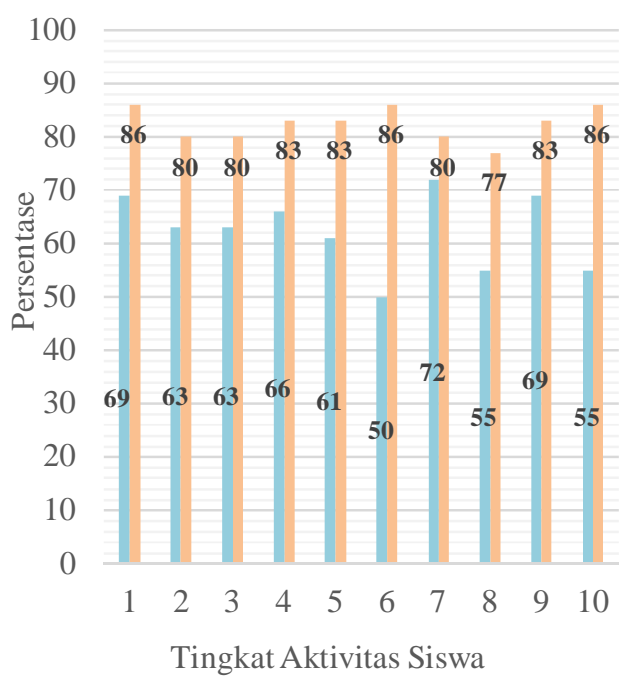

Gambar 6: Observasi Aktivitas Siswa Siklus I \& II

Bila ditinjau dari segi aktivitas siswa selama tindakan diberikan pada siklus I diperoleh rata-rata aktivitas belajar siswa sebesar $63 \%$ berada pada kategori "Cukup" sehingga .belum memenuhi kriteria yang ditentukan. Hal ini disebabkan belum maksimalnya siwa melakukan aktivitas sebagaimana pada aspek-aspek pengamatan. Kemudian selama tindakan pada siklus II diperoleh aktivitas siswa sebesar 82\% berada pada kategori "Baik". Hal ini menunjukkan bahwa kriteria yang diharapkan telah tercapai. Hal ini berarti ada peningkatan dari siklus I ke siklus II 
Iwan Setiawan Nasution, dkk. Model Pembelajaran Connecting, Organizing ...

\section{SIMPULAN}

\begin{abstract}
Hasil belajar siswa setelah diberi perlakuan dengan meningkatkan kemampuan kreativitas matematika siswa. Dari rata-rata hasil tes kemampuan kreativitas siswa yaitu 53\% pada siklus I menjadi $82 \%$ pada siklus II. Berdasarkan hasil siklus I dan II terdapat peningkatan kemampuan kreativitas siswa sebesar $29 \%$. Berdasarkan data hasil penelitian melalui observer siswa diperoleh presentase $53 \%$ aktivitas belajar matematika siswa siklus I, dan $82 \%$ pada siklus II. Jadi dapat disimpulkan bahwa siswa sangat termotivasi dalam belajar dengan menggunakan model pembelajaran Connecting, Organizing, Reacting and Extending (CORE) yang termasuk pada kategori "baik" dengan peningkatan $29 \%$.
\end{abstract}

\section{DAFTAR PUSTAKA}

Hariyanto. 2016. Penerapan Model CORE Dalam Pembelajaran Matematika Untuk Meningkatkan Kemampuan Komunikasi Matematik Siswa. Jurnal Gammath 1(2).

Karkockiene, D. 2005. Creativity: Can it be Trained? A Scientific Educology of Creativity. cdInternational Journal of Educology, Lithuanian Special Issue. pp.52.

Richardo, R., Mardiyana \& Dewi. R. S. S. 2014. Tingkat Kreativitas
Siswa Dalam Memecahkan

Masalah Matematika Divergen Ditinjau Dari Gaya Belajar Siswa. Jurnal Elektronik Pembelajaran Matematika 2(2).

Samosir, B. S., \& Andes. F 2018. Upaya Meningkatkan

Pemahaman Konsep Dan Disposisi Matematis

Menggunakan Model

Pembelajaran Treffinger Di Sma Negeri 1 Angkola Barat. PeTeKa Jurnal Penelitian Tindakan Kelas Dan Pengembangan Pembelajaran 1(2).

Sanjaya, Wina. 2010. Penelitian Tindakan Kelas. Jakarta: Bumi Aksara.

Siregar, N. A. R., Pinta D. S., \& Lukman E. H. 2018. Pengaruh Model Pembelajaran CORE Terhadap Kemampuan Berpikir Kritis Dan Disposisi Matematis Ditinjau Dari Kemampuan Awal Matematika Siswa SMA Negeri Di Jakarta Timur. Jurnal Penelitian dan Pembelajaran Matematika 11(1).

Sriraman, B. 2011. The Elements of Creativity and Giftedness in Mathematics. Rotterdam: Sense Publishers.

Susanto, Ahmad. 2012. Teori Belajar Dan Pembelajaran. Jakarta: Penerbit Kencana. 